\title{
Relasi Pendidik Dengan Peserta Didik di Era Millennial Dalam Pendidikan Islam
}

\author{
Muhamad Faizul Amirudin dan Yesi Arikarani \\ STAI Bumi Silampari Lubukinggau \\ amirudin.mfgcf@gmail.com yesiarikarani@gmail.com
}

\begin{tabular}{ll}
\hline & Abstract \\
\hline Article History & The problems that arise in this era are the \\
Received :24-08-2020 & first concerns about the replacement of \\
Revised :18-09-2020 educators with robotics or Artificial \\
Accepted :22-09-2020 & Intelligence (AI) when entering the era of \\
\hline Keywords: & the industrial revolution 4.0. Second, the \\
Relations, & development of various kinds of \\
Educators, & sophisticated technology has led to changes \\
Students, & in attitudes and behavior between educators \\
Millennial era & and students in the field of education, such \\
& as changes in communication ethics between \\
& the two, weakening respect and appreciation \\
& for educators. Third, educators are required \\
& to be adaptive to the development of modern \\
& technology and utilize it in practice in the \\
& world of education. This research is a \\
& literature review (library reaserch). The \\
& relationship between educators and students \\
& in the millennial era in Islamic education \\
& cannot be completely replaced by machines \\
& or robotics, because in the concept of \\
& Islamic education there is a planting of \\
attitudes towards students which in this case \\
requires the direct role of an educator.
\end{tabular}

\section{Pendahuluan}

Pendidikan merupakan suatu rangkaian secara keseluruhan yang terdiri dari beberapa rangkaian yang saling berhubungan antara satu dan lainnya yaitu pada bagian pendidik dengan peserta didik. dalam sebuah pendidikan terjadilah sebuah interaksi antara pendidik dengan peserta didik yang menurut Sukmadinata sebagai inti dari pendidikan daam upaya membantu peserta didik mencapai tujuan 
pendidikan (Sukmadinata 2016). Interaksi pendidikan tersebut dapat terjadi di pendidikan formal, informal dan nonformal. Bentuk interaksi pendidikan mengalami perubahan sesuai dengan perkembangan ilmu pengetahuan dan teknologi, serta perubahan keadaan social, budaya, dan politik. Era millennial menghadirkan berbagai permasalahan baru di dunia pendidikan, pertama tergantikannya beberapa peran pendidik oleh mesin atau robotic yang sering disebut dengan istilah Artificial Intelligence (AI). Dengan adanya teknologi canggih peserta didik di era millennial bisa mengakses pengetahuan ke berbagai penjuru dunia hanya bermodalkan smartphone atau PC (computer) dan jaringan internet. kedua memudarnya etika interaktisi yang baik antara guru dengan siswa. Teknologi komunikasi pada era millennial mengubah cara interaksi antara seorang pendidik atau guru dengan siswa, walaupun adanya kedekatan pada keduanya bukan berarti menghilangkan batasbatas adab sebagai seorang murid kepada guru. Hal ini sering kita lihat sekarang dalam dunia pendidikan rasa hormat dan penghargaan peserta didik kepada pendidik mulai mengalami pergeseran nilai dengan adanya media social seperti Whatsapp, messenger, instagram dan media social lainnya. Hal ini bukannya melarang interaksi melalui media social tersebut namun walaupun melalui media komunikasi yang canggih dengan tetap memperhatikan etika dalam komunikasi dalam menggunakannya. ketiga tuntutan penguasaan terhadap teknologi yang diaplikasikan dalam pendidikan. Mau tidak mau ketika teknologi merambah ke dalam pendidikan pendidik dituntut untuk selalu update keilmuannya agar mampu memanfaatkan teknologi dalam mempermudah mencapai tujuan pendidikan. Permasalahan tersebut harus diantisipasi agar tidak menimbulkan permasalahan yang lebih rumit lagi dalam pendidikan. Menurut Rahmawati Pemanfaatan teknologi dalam proses belajar mengajar di era disrupsi menjadi persyaratan dasar. Pendidikan agama Islam sebagai salah satu yang akan terkena imbas gelombang teknologi harus mampu memanfaatkan teknologi sebagai peningkatan mutu Pendidikan Agama Islam (Rahmawati 2018, 57). Artinya respon tanggap terhadap perkembangan teknologi dari berbagai pihak dalam pendidikan di era millennial ini sebuah keharusan, karena dalam proses pendidikan keadaan dari peserta didik yang saat ini disebut sebagai generasi millenal menentukan cara yang berbeda dalam melakukan pendekatan pendidikannya. 
menurut penelitian Lyons (2004) yang dikutip Putra menyatakan ciri-ciri dari generasi $\mathrm{Y}$ atau yang disebut generasi millenial diantaranya karakteristik masing-masing individu berbeda tergantung dimana ia dibesarkan, strata ekonomi, dan sosial keluarganya, pola komunikasinya sangat terbuka dibanding generasigenerasi sebelumnya, pemakai media sosial yang fanatik dan kehidupannya sangat terpengaruh dengan perkembangan teknologi, lebih terbuka dengan pandangan politik dan ekonomi, sehingga mereka terlihat sangat reaktif terhadap perubahan lingkungan yang terjadi di sekelilingnya, memiliki perhatian yang lebih terhadap kekayaan (Putra 2016, 12). Berdasarkan ciri di atas karakteristik generasi millennial dipengaruhi oleh faktor-faktor eksternal yang mempengaruhinya seperti lingkungan, social keluarganya. Termasuk teknologi yang mempengaruhi kehidupannya seperti game, social media yang mengalahkan kehidupan nyata mereka dan lebih senang menghabiskan waktu dengan smartphonnya atau PC di dunia maya.

Perkembangan teknologi merupakan sebuah keniscayaan yang dapat menimbulkan hal positif dan negative dalam pendidikan. Pendidikan sendiri memiliki peran yang besar dalam mengatasi dampak negative yang ditimbulkan oleh teknologi tersebut. Karena pendidikan merupakan system yang saling terkait dan saling mempengaruhi satu sama lainnya diantaranya antara pendidik dengan peserta didik, jadi dalam tulisan ini ingin mengkaji bagaimana relasi seorang tenaga pengajar dengan siswa di era millennial dalam pendidikan Islam. Apakah dengan adanya teknologi menggeser peran dan fungsinya yang selama ini sudah berlangsung dalam pendidikan?

\section{Metode Penelitian}

Dalam penelitian ini menggunakan jenis library reaserch (kepustakaan). Penelitian yang dilakukan dengan cara mengkaji dan menganalisis sumber primer dari buku, jurnal ilmiah, artikel dan dokumen yang relevan dengan pembahasan dengan tujuan untuk memecahkan suatu masalah yang pada dasarnya tertumpu pada study kritis dan mendalam dengan bahan-bahan pustaka yang relevan. Teknik analisis deduktif dan induktif secara deskriptif digunakan untuk menganalisis sumber-sumber yang membahas relasi pendidik dan peserta didik di era millennial dalam pendidikan Islam. 


\section{Pembahasan}

\section{Karakteristik generasi millennial}

Kriterian yang digunakan secara umum untuk membedakan generasi menurut twenge (2006) (dalam Putra, 2016) adalah tahun kelahiran dan peristiwa-peristiwa yang terjadi secara global. Salah satu penelitian yang membedakan antar generasi tersebut adalah penelitian Bencsik csikos dan juhes (dalam Putra, 2016) yang dapat dilihat dalam table berikut:

Tabel. 1

Perbedaan Generasi

\begin{tabular}{|c|l|l|}
\hline No & Tahun Kelahiran & \multicolumn{1}{|c|}{ Nama Generasi } \\
\hline 1 & $1925-1946$ & Veteran Generation \\
\hline 2 & $1946-1960$ & Baby Boom Generation \\
\hline 3 & $1960-1980$ & X Generation \\
\hline 4 & $1980-1995$ & Y Generation \\
\hline 5 & $1995-2010$ & Z Generation \\
\hline 6 & $2010+$ & Alfa Generation \\
\hline
\end{tabular}

Karakteristik tiap generasi di atas memiliki perbedaan sendirisendiri, veteran generation atau sering juga disebut sebagai silent generation adalah generasi yang konservatif dan disiplin. Baby boom generation adalah generasi yang materialistis dan berorientasi waktu. Generasi X adalah generasi yang lahir pada tahun-tahun awal dari perkembangan teknologi dan informasi seperti penggunaan PC (computer), video games, tv kabel, dan internet. Generasi $\mathrm{Y}$ atau disebut millennium/millennial yaitu generasi yang banyak menggunakan teknologi komunikasi instan seperti email, SMS, instant messaging dan media sosial seperti facebook dan twitter, dengan kata lain generasi $\mathrm{Y}$ adalah generasi yang tumbuh pada era internet booming. generasi $\mathrm{Z}$ (iGeneration) atau generasi internet. Generasi $\mathrm{Z}$ memiliki kesamaan dengan generasi $\mathrm{Y}$, tapi generasi $\mathrm{Z}$ mampu mengaplikasikan semua kegiatan dalam satu waktu (multi tasking) seperti menjalankan sosial media menggunakan ponsel, browsing menggunakan PC, dan mendengarkan musik menggunakan headset (Putra 2016). Sedangkan generasi alfa Menurut McCrindle bahwa generasi milenial yang paling banyak diantara yang pernah adalah anak-anak. Kemudian generasi yang paling berpengaruh pada kehidaoan manusia adalah generasi Alfa. Yang menjadi pengaruhnya 
adalah pada ukuran usia manusia yang masi muda dan pada faktor roda perekonomian dunia. (Matranews 2019).

Hasil penelitian di atas menunjukkan bahwa yang disebut generasi millennial pada intinya adalah generasi yang hidup berdampingan dengan berbagai macam teknologi canggih, dan teknologi tersebut sudah menjadi bagian dari kehidupannya sehingga mempengaruhi dari cara pandang kehidupannya ke dalam berbagai hal. Untuk era millennial sendiri mengutip dari Echols (1980) menyatakan millennial berasal dari kosa kata bahasa Inggris millennium atau millennia yang berarti masa seribu rahun (Nata 2018). Lebih lanjut Nata menjelaskan era milenial dijadikan sebutan untuk sebuah masa yang terjadi setelah era global, atau era modern sehingga dapat pula disebut erapost-modern.

Tujuan mengetahui karakteristik peserta didik era millennial menjadi penting dalam melakukan sebuah pendekatan bagi pendidik untuk menyesuaikannya dalam proses pendidikan. Karena pendekatan atau model pembelajaran juga membutuhkan sebuah inovasi seiring dengan perkembangan zaman. Sesuai yang diamantkan dalam Undang-Undang tentang Guru dan Dosen No 14 Tahun 2005 pasal 10 ayat 1 bahwa salah satu uraian tugas guru pada poin e yaitu memanfaatkan teknologi informasi untuk berkomunikasi dan mengembangkan diri.

\section{Pendidik dan peserta didik dalam pendidikan Islam}

Terjadinya sebuah pendidikan bilamana adanya pendidik dan peserta didik. Keberadaannya dalam pendidikan menjadi komponen utama ketika berbicara tentang pendidikan. Pendidik dalam undangundang Sisdiknas pasal 1 nomor 6 diartikan sebagai tenaga kependidikan yang berkualifikasi sebagai guru, dosen, konselor, pamong belajar, widyaiswara, tutor, instruktur, fasilitator, dan sebutan lain yang sesuai dengan kekhususannya, serta berpartisipasi dalam menyelenggarakan pendidikan (UU No. 20 Tahun 2003).

Pendidik dalam pendidikan Islam diartikan lebih luas lagi sebagaimana yang dinyatakan Umar bahwa pendidik adalah orang yang bertanggung jawab terhadap perkembangan peserta didik dengan upaya mengembangkan seluruh potensi peserta didik baik afktif (rasa), kognitif (cipta), maupun psikomotorik (karsa) (Umar 2010, 83). Lebih lanjut umar membedakan pendidik dalam pendidikan Islam terbagi menjadi dua yaitu pendidik kodrat 
merupakan orang tua dan pendidikan pada anak. Sebab orang tua mempunyai kewajiban mendidik anaknya sebagai amanah langsung yang diberikan Allah Swt yang disebutkan dalam firman-Nya Alquran Surat At-Tahrim (66) ayat 6:

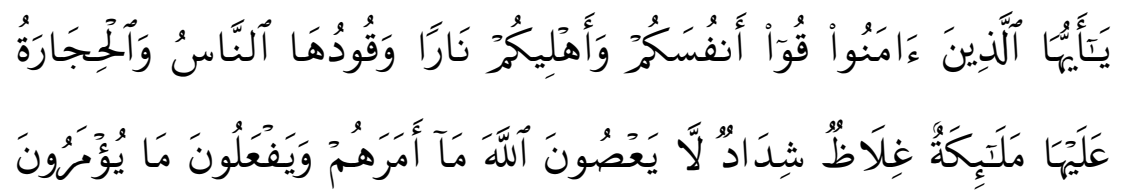

Artinya: Hai orang-orang yang beriman, peliharalah dirimu dan keluargamu dari api neraka yang bahan bakarnya adalah manusia dan batu; penjaganya malaikatmalaikat yang kasar, keras, dan tidak mendurhakai Allah terhadap apa yang diperintahkan-Nya kepada mereka dan selalu mengerjakan apa yang diperintahkan.

Dari ayat di atas memberikan penjelasan bahwa orang tua mukmin secara otomatis menjadi pendidik. Sebagaimana dinyatakan Al-Maraghi yang menafsirkan untuk memelihara dan menyelamatkan keluarga dari siksa api neraka dapat dilakukan dengan mengajar, menasehati, dan mendidik mereka.

Pendidik yang kedua adalah pendidik jabatan seperti guru, konselor, dan administrator karena jabatan. Pendidik jabatan ini pada hakikatnya pendidik yang membantu orangtua dalam mendidik anaknya karena memiliki berbagai keterbatasan (Umar 2010, 86).

Term pendidik dalam pendidikan Islam terdapat beberapa istilah dengan makna yang berbeda; pendidik disebut murabbi sering dijumpai dalam kalimat yang orientasinya lebih mengarah pada pemeliharaan, baik yang bersifat jasmani atau rohani. Mu'allim dipakai dalam membicarakan aktivitas yang lebih berfokus pada pemberian atau pemindahan ilmu pengetahuan (baca: pengajaran), dari seorang yang tahu kepada seorang yang tidak tahu. Mu'addib menurut al-Atas, lebih luas dari istilah mu'allim dan lebih relevan dengan konsep pendidikan Islam (Ramayulis 2008, 58).

Walaupun banyak term tentang pendidik dalam pendidikan Islam namun dari uraian di atas dapat disimpulkan bahwa pada hakikatnya pendidik dalam pendidikan Islam adalah orang yang 
bertanggung jawab dalam perkembangan potensi peserta didik dari aspek sikap (afektif), pengetahuan (kognitif), dan keterampilan (psikomotorik) sesuai dengan nilai-nilai Islam. Istilah pendidik sendiri akan menyesuaikan pada lingkungan dimana terjadinya proses pendidikan tersebut seperti orang tua di rumah, guru di sekolah, dosen di Perguruan Tinggi, Kyai di Pesantren dan seterusnya.

Komponen peserta didik dalam pendidikan dijelaskan dalam Undang-undang nomor 20 tahun 2003 tentang Sisdiknas pasal 1 ayat 4 menjelaskan peserta didik adalah anggota masyarakat yang berusaha mengembangkan potensi diri melalui proses pembelajaran yang tersedia pada jalur, jenjang, dan jenis pendidikan tertentu. Menurut Suharto peserta didik adalah orang yang belum dewasa dan memiliki sejumlah dasar (fitrah) yang perlu dikembangkan (Suharto 2011, 119) Sedangkan dalam pendidikan Islam peserta didik bukan hanya anak-anak, namun juga orang dewasa yang masih berkembang baik fisik maupun psikis (Umar 2010, 103).

Tafsir membagi sebutan pelajar menjadi tiga, yaitu murid; adalah khas pengaruh agama Islam. Istilah murid menunjukkan kepatuhan murid pada guru (mursyid)nya. Anak didik mengandung pengertian guru menyayangi murid seperti anaknya sendiri. Faktor kasih sayang salah satu kunci keberhasilan pendidikan, dan peserta didik. Istilah murid. Peserta didik menekankan pentingnya murid berpartisipasi dalam proses pembelajaran (Tafsir 2006, 165). Dari beberapa istilah peserta didik di atas dapat disimpulkan bahwa peserta didik dalam pendidikan Islam adalah seseorang yang berusaha untuk mengembangkan seluruh potensi atau fitrahnya melalui proses pendidikan. Sedangkan penyebutan peserta didik juga bermacammacam seperti halnya pendidik, misalkan siswa untuk di sekolah atau madrasah, mahasiswa di perguruan tinggi, santri di pondok pesantren, jamaah di majelis ta'lim dan sebagainya.

Pembahasan pendidik dan peserta didik di atas secara terpisah belum dikatakan sebagai pendidikan ketika tidak ada Interaksi antara pendidik dengan peserta didik. Undang-undang tentang sisdiknas menjelaskan Pendidikan adalah usaha sadar dan terencana untuk mewujudkan suasana belajar dan proses pembelajaran agar peserta didik secara aktif mengembangkan potensi dirinya untuk memiliki kekuatan spiritual keagamaan, pengendalian diri, kepribadian, kecerdasan, akhlak mulia, serta keterampilan yang diperlukan dirinya, masyarakat, bangsa dan Negara (UU No. 20 Tahun 2003). Sedangkan 
Pendidikan Islam menurut Al-Syaebani adalah usaha mengubah tingkah laku individu dalam kehidupan pribadinya atau kehidupan kemasyarakatanya dan kehidupan dalam alam sekitar melalui proses kependidikan dengan landasan nilai-nilai Islam (Arifin 2009, 15). Menurut Arifin pendidikan Islam berarti system pendidikan yang dapat memberikan kemampuan seseorang untuk memimpin kehidupannya sesuai dengan cita-cita dan nilai-nilai Islam yang telah menjiwai dan mewarnai corak kepribadiannya (Arifin 2009, 7).

Pendidik, peserta didik, tujuan pendidikan dan proses pembelajaran merupakan komponen pokok pendidikan, setiap kegiatan pendidikan, yang berlangsung dalam hubungan pendidikan disebut sebagai situasi pendidikan (Prayitno 2009, 43). Dari pendapat di atas kita pahami bahwa terjadinya pendidikan apabila ada dari komponen-komponen pokok pendidikan di atas saling berinteraksi melalui pengjaran, pelatihan, dan pendidikan.

\section{Relasi pendidik dan peserta didik di era millennial}

Era millennial sangat berkaitan erat dengan teknologi yang menjadi trend dalam kehidupan. era millennial ini merupakan kelanjutan dari era selanjutnya yang dalam Nata disebutkan sebagai era post modern yang masih sama memiliki cirri-ciri era global seperti persaingan yang ketat sebagai akibat dari pasar bebas (free market); tuntutan untuk memperoleh perlakuan yang lebih adil, egaliter, manusiawi, dan demokratis, sebagai akibat dari fragmentasi politik; hegemoni politik sebagai akibat dari adanya kesaling tergantungan (interdependensi); harus belajar kembali sebagai akibat dari kemajuan ilmu pengetahuan dan teknologi; serta adanya kemerosotan moral (moral decadency) sebagai akibat dari masuknya budaya baru yang tidak sejalan dengan nilai-nilai ajaran agama (Nata 2018, 11).

Ciri-ciri tersebut selanjutnya timbul menjadi tantangan baru yang harus dihadapai dalam pendidikan. Seperti kemajuan ilmu pengetahuan dan teknologi yang saat ini sudah masuk di lingkungan pendidikan mangharuskan pendidik untuk beradaptasi menguasai teknologi pendidikan. Pendidik penting menguasai teknologi pendidikan supaya dalam proses pendidikan mampu menyesuaikan dengan keadaan peserta didik yang disebut sebagai generasi millennial. Bisa dibayangkan ketika guru di era millennial ini yang masih gagap teknologi, tidak paham internet dan masih menggunakan 
model pembelajaran lama menganggap bahwa peserta didik adalah objek pendidikan yang saat ini sudah mulai berubah paradigma bahwa peserta didik adalah subjek dalam pendidikan. Keadaan peserta didik era millennial berbeda dengan karakteristik peserta didik sebelumnya, di era millennial saat ini kehidupan peserta didik sudah berdampingan dengan smartphone dan internet dan mampu mengoperasikan dari teknologi canggih tersebut. Mereka bisa mengakses berbagai pengetahuan dari berbagai penjuru melalui smartphonenya yang biasa disebut dunia sekarang sudah dalam genggaman. Memang beberapa ciri era millennial salah satunya adalah mereka menyukai sesuatu yang instan sebagaimana pendapat Tapscott dalam (Nata 2018, 11) ciri-ciri sikap dan perilaku manusia era millennial yaitu suka dengan kebebasan, senang melakukan personalisasi, mengandalkan kecepatan informasi yang instant (siap saji), suka belajar, bekerja dengan lingkungan inovatif, aktif berkolaborasi, dan hyper technology.

Dari ciri di atas dengan mengandalkan kecepatan informasi yang instan dengan mudahnya di era millennial melakukan aktifitas dangan adanya teknologi internet dan smartphone tersebut, sebagai contoh saat ini orang belanja sudah tidak lagi harus ke mall atau toko. Penyedia jasa jual beli online saat ini sudah banyak di Indonesia, bahkan untuk makan saja orang tidak harus pergi ke rumah makan atau warung, mereka bisa memesan lewat aplikasi Grab Food atau Go food. Inilah yang disebut sekarang sebagai era revolusi industry 4.0 yang menimbulkan inovasi disruptif (Disruptif Innovation). Era disruptif adalah masa di mana banyak bermunculan inovasi yang tidak terlihat, tidak disadari oleh organisasi, instansi, perusahaan, atau lembaga yang telah mapan sehingga mengganggu jalannya tatanan sistem lama yang ada di dalamnya dan berpotensi menghancurkan sistem lama tersebut (Marlina Widiyanti 2019).

Aspek pendidikan juga terdampak dengan adanya innovasi disruptif saat ini. Misalnya, untuk megakses pengetahuan peserta didik bisa berselancar di internet melaluai smartphone ataupun PC dengan koneksi internet, mereka bisa belajar tutor lewat video Youtube, ataupun free Source online, e-learning, e-book, e-journal. Adanya innovasi pendidikan tersebut yang diakibatkan oleh kemajuan teknologi bila disalahartikan maka peserta didik akan beranggapan untuk mendapatkan pengetahuan dan skill mereka bisa saja hanya lewat fasilitas yang serba online tersebut. Hal inilah yang 
berdampak terhadap pandangan mereka tentang keberadaan dari pendidik dalam proses pendidikan. Hal ini bagi beberapa kalangan sudah terjadi, misalkan dalam sebuah majelis atau ceramah dengan seorang ustadz terkenal mereka menganggap tidak harus hadir pada acara tersebut karena cukup dengan browsing di youtube sudah bisa mendengarkan kajian dari ustazd tersebut.

Dunia pendidikan pada Negara maju yang serba elektronik dan robotic mengembangkan pendidikan berbasis teknologi, hal ini menimbulkan kekhawatiran di beberapa kalangan pendidikan digantikan oleh Arificial Intelegent (AI). AI merupakan sebuah pengembangan dari neurosince yang menjadikan otak sebagai objek kajiannya sehingga menemukan pola khusus. Pola ini yang kemudian menjadi formula umum dari kinerja otak selama ini dan aktualisasi formula otak dan kepala yang selama ini kita kenal dengan computer (Mubarak 2018, 86). kita mengetahui saat ini teknologi computer semakin canggih dengan semakin meningkatnya kapasitas prosesor sebagai otaknya, dan Random Access Memory (RAM) sebagai system yang menghubungkan otak dengan perangkat lainnya secara sistematis dan memori yang berfungsi menyimpan seluruh dokumen. Mubarak menjelaskan dengan miningkatnya kapasitas prosesor, RAM, dan memori tersebut melebihi kapasitas manusia yang pada nantinya akan mampu bekerja melebihi kemampuan manusia itu sendiri. Seperti tes yang dilakukan pada computer cerdas di Tiongkok memperoleh nilai lebih baik dari manusia dewasa pada tes IQ (Schwab 2019, 208). Dan pada tahap berikutnya yang akan dikembangkan adalah human feeling "perasaan manusia" yang sebelumnya belum ada (Mubarak 2018, 88).

Empat komponen di atas yang membuat tech developer mengembangkan perangkan yang bernama Artificia Intelegent atau disebut "kepintaran/kecerdasan buatan". Namun di sisi lain menurut Mubarak ada beberapa hal yang tidak bisa digantikan oleh teknologi dalam proes pendidikan yaitu instrument, rasa, bahasa, dan karakter (Mubarak 2018, 80-84). Mubarak mejelaskan bahwa instrument manusia yan tidak dimilki oleh computer adalah hati, kalaupun hati sudah diadopsi oleh ahli robotic yang bernama artifiacial intelegent (AI) manusia masih memiliki kelebihan yaitu hidup, karena energy hidup dari Tuhan berbeda dengan energy listrik. Rasa adalah keterkaitan emosi manusia dengan manusia atau objek yang menjadi tujuannya, karena akan berbeda ikatan rasa guru manusia dengan 
guru mesin. Bahasa dalam proses pendidikan merupakan pengikat interaksi manusia. Karena bahasa dari guru yang penuh dengan rasa akan berbeda dengan bahasa oleh mesin, mulai dari kosakata, intonasi, artikulasi, dan sastra yang tinggi menjadi pembedanya. Karakter merupakan perbedaan yang paling uggul manusia sebagai guru, guru manusia merupakan guru yang memiliki akhlak, sikap, attitude, dan behavior (Mubarak 2018). Dari pendapat tersebut dapat disimpulkan bahwa sehebat apapun teknologi modern maka tidak akan mampu menggantikan peran pendidik terutama dalam pendidikan Islam karena pendidik memiliki beberapa kelebihan pemberian Tuhan dibandingkan dengan mesin.

Bila kita melihat hasil beberapa penelitian tentang penggunaan internet dan pemanfaatannya di Indonesia menempati posisi cukup tinggi. Seperti penelitian yang dilakukan oleh Asosiasi Penyelenggara Jasa Internet (APJII) pada tahun 2018 menyatakan terdapat 171,17 juta jiwa di Indonesia yang memakai internet. Angkanya naik 10,12\% dibandingkan tahun 2017 penggunanya mencapai 142 juta jiwa. Menurut survei tersebut penggunaan internet akan terus meningkat yang disebabkan beberapa factor yaitu seiring makin luasnya jangkauan layanan internet di tanah air, semakin banyaknya menara Base Transceiver Station (BTS) yang dibangun oleh para operator maupun penyedia jasa layanan seluler, pembangunan jaringan kabel fiber optik Palapa Ring di Indonesia, terutama bagian timur. Dan banyaknya pekerjaan yang harus diselesaikan dengan menggunakan bantuan jaringan internet (Annur dan Tobing 2019). Berikut dapat dilihat persentase pengguna internet berdasarkan wilayahnya;

Table 2. Kontribusi pengguna internet per wilayah

\begin{tabular}{|c|l|c|}
\hline No & \multicolumn{1}{|c|}{ Pulau } & Persentase \% \\
\hline 1 & Jawa & $55 \%$ \\
\hline 2 & Sumatera & $21 \%$ \\
\hline 3 & Sulawesi-Maluku-Papua & $10 \%$ \\
\hline 4 & Kalimantan & $9 \%$ \\
\hline 5 & Bali dan Nusa Tenggara & $5 \%$ \\
\hline
\end{tabular}

Data diolah dari hasil surve APJII (Annur dan Tobing 2019)

Dari hasil survey di atas penggunaan internet terbesar ada di pulau Jawa dan Nusa Tenggara paling kecil dikarenakan fasilitas akses internet masih kurang di banding pulau Jawa dan Sumatera. 
Makannya ada perencanaan dari pemerintah untuk peningkatan fasilitas tersebut ke depan yang di fokuskan ke bagian timur.

Sedangkan untuk pemanfaatan internet di Indonesia dapat dilihat pada gambar berikut:

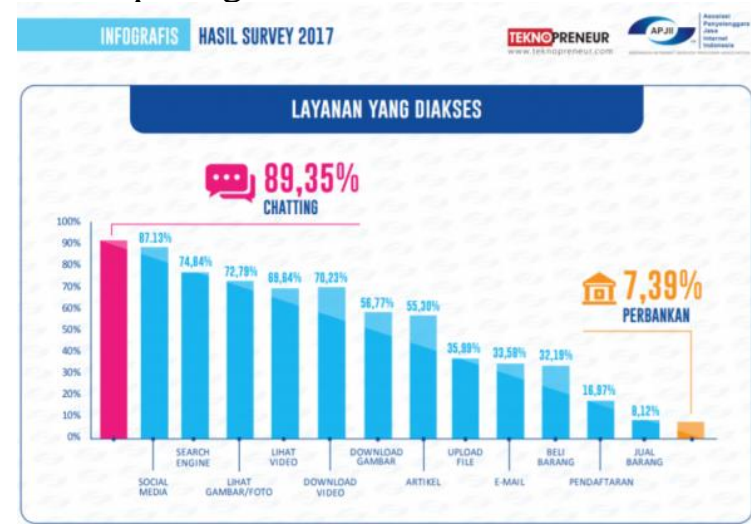

Gambar 1.

Pemanfaatan internet di Indonesia berdasarkan survey APJII 2017

Dari gambar di atas ternyata untuk pemanfaatan internet diIndonesia posisi teratas adalah penggunaan chatting dan social media urutan kedua. untuk bidang pendidikan penggunaan internet di indonesi mencapai 55,3\% akses internet adalah untuk mencari artikel dan $49,7 \%$ melihat video tutorial. Sisanya, memanfaatkan inernet untuk berbagi video edukasi atau artikel, kursus secara online, dan mendaftar sekolah (Setyowati dan Pingit 2018).

Statistik hasil survei di atas dapat menjadikan alasan bahwa menjalarnya teknolgi di bidang pendidikan di era millennial dan era selanjutnya adalah sebuah keniscayaan. Pendidik diharapkan secara optimal untuk update pengetahuan sesuai dengan perkembangan ilmu pengetahuan dan teknologi. Bila teknologi dimanfaatkan secara positif maka akan berdampak positif pada peningkatan mutu pendidikan sebaliknya juga, bila dimanfaatkan untuk hal yang negative maka akan berdampak negative pula. Seorang pengajar memiliki posisi yang paling utama dimana perannya tidak akan bisa digantikan oleh teknologi, karena pendidikan bukan hanya sekedar transfer pengetahuan namun juga penanaman sikap dan pembekalan keterampilan yang semuanya tidak bisa dilepaskan dari nilai-nilai Islam. 
Sesuai dengan perkembangan ilmu pengetahuan dan teknologi di era millennial maka hubungan antara pendidik dan peserta didik mengalami beberapa perubahan paradigma diantaranaya sumber pengetahuan bukan hanya guru saja, peserta didik bukan lagi dijadikan sebagai objek belajar namun sebagai subjek belajar, dari teacher oriented ke student oriented, dari Teacher Active Learning (TAL) ke Students Active Learning (SAL).

Perubahan paradigma di atas hanya sebagai inovasi dalam beberapa hal saja, namun ketika melakukan inovasi dalam pendidikan tetap harus mempertahankan nilai-nilai Islam. Pendidikan Islam sendiri memandang kedudukan pendidik memiliki tempat yang mulia. Seperti diungkapkan oleh Al-Ghazali yang dinukilnya dari perkataan ulama "pendidik merupakan pelita (siraj) segala zaman, orang yang hidup semasa dengannya akan memperoleh pancaran cahaya (nur) keilmiahannya. Andaikata dunia tidak ada pendidik, niscaya manusia seperti binatang, sebab mendidik adalah upaya mengeluarkan manusia dari sifat kebinatangannya kepada sifat insaniyyah dan ilahiyyah" (Umar 2010, 86-87). Kalau kita hayati pernyataan di atas sunggu luar biasa keberadaan dan kedudukan guru dalam pendidikan Islam. Mereka tidak pernah lekang oleh zaman dan perannya yang begitu mulia yaitu membimbing manusia menjadi Abdullah dan khalifah fiil ard".

Pendidikan Islam juga member peringatan bagi yang belajar tanpa adanya bimbingan guru, bahkan di kalangan pesantren ada ungkapan yang sering kita dengar "مَن لا شيخخ له؛ فنشيخُه الثيطان " artinya "Barangsiapa yang tidak punya guru, maka gurunya adalah syaitan" (PCNU 2017). Tentu saja prinsip ini masih bisa kita terapkan terutama bidang ilmu agama, karena guru dibutuhkan untuk memverifikasi dan menjaga otentik konten apabila ada kesalahan dalam memahami dan menafsirkan ayat Alquran ataupun hadits hanya secara otodidak. Selanjutnya dalam pendidikan Islam terkhusus di lingkungan pesantren adanya pertimbangan memilih guru dengan melihat sanad guru-gurunya yang mutawatir. Bukan hanya sanad keilmuannya saja yang menjadi pertimbangan namun dalam pendidikan Islam ada istilah keberkahan ilmu dari seorang guru seperti yang dinyatakan dalam kitab terjemah Ta'limul Muta'allim;

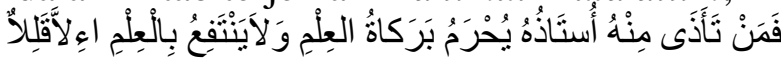
Artinya: "Barang siapa melukai hati gurunya, maka tertutuplah keberkahan ilmunyadan hanya sedikit manfaat ilmu yang dapat 
Dikalangan pesantren dan lingkungan pendidikan Islam tertentu ada sisi keberkahan dari keilmuan guru yang perlu dicari, tentunya dengan syarat-syarat yang harus dimilki oleh guru sebagai seorang pendidik dalam Islam. Ini menunjukkan bahwa kedudukan guru dalam pendidikan bukan hanya dilihat dari materi (jasadiyah) saja tapi dari immaterinya (ruhaniyyah) ada nilai-nilai ilahiyyah yang bisa dijadikan landasan dalam menjalin hubungan dengan pendidik.

Hal inilah yang perlu diperhatikan ketika menghadapi era millennial pentingnya menghormati dan menghargai pendidik menentukan dari hasil pendidikan. Mungkin pada lingkungan pesantren tradisi ini masih bisa kita lihat hingga sekarang, namun pada lingkungan pedidikan tertentu seperti sekolah terjadi pergeseran nilai dalam menghormati pendidik. Sebagaimana diungkapkan Klaus (Schwab 2019, 177) bahwa dampak yang bisa positif atau negative dari revolusi industry terutama revolusi neural salah satunya adalah ketidaksopanan komunikasi. Memang di era millennial ini salah satu yang menjadi perubahan adalah kedekatan antara seorang pengajar dengan siswa yang menganggap teman di dunia pendidikan, namun kedekatan tersebut bukan berarti menghilangkan etika dan adab antara peserta didik dan pendidik yang sering kita lihat dalam praktik pendidikan.

Hubungan pendidik dan peserta didik di era millennial dalam pendidikan Islam selanjutnya adalah permasalahan degradasi moral dan akhlak. Pentingnya pendidik dalam membimbing, membiasakan, menasihati, serta memberikan suri tauladan kepada peserta didik dalam menanamkan nilai-nilai kepada peserta didik agar menjadi manusia berakhlakul karimah adalah yang tidak bisa dilakukan oleh teknologi. Sebagaimana ungkapan Mubarak "kalau pendidkan hanya bertujuan transfer pengetahuan maka teknologi adalah guru yang paling hebat, akan tetapi dalam memanusiakan manusia, pendidikan model itu tidak cukup" (Mubarak 2018, 179). Pernyataan tersebut menunjukkan bahwa hubungan pendidik dengan peserta didik bukan hanya sebatas "pengajaran" namun "pembelajaran".

Maka dapat di pahami bahwa pernyataan diatas memiliki relasi antara pendidik dengan peserta didik di era millennial pendidikan Islam sangat erat dan urgen. Pendidik dan peserta didik juga merupakan komponen utama yang tidak bisa dihilangkan dalam 
mencapai tujuan-tujuan pendidikan. Sebagaimana pernyataan Mubarak bahwa relasi guru atau mursyid dengan murid, Kyai dengan santri merupakan hubungan kemanusiaan yang memiliki nilai strategis dalam Islam (Mubarak 2018, 177).

\section{Simpulan}

Perkembangan ilmu pengetahuan dan teknologi di era millennial (post modern) menimbulkan dampak positif dan negative dalam pendidikan Islam, tergantung dari pemanfaatannya bagi penggunanya. Pendidik, peserta didik, dan tujuan pendidikan adalah komponen-komponen yang terdapat dalam pendidikan, hubungan diantara tenaga pendidik dengan peserta didik merupakan inti dari pendidikan dan terdapat relasi yang erat antara keduanya yang memiliki hubungan kemanusiaan. Untuk itu pendidik dalam pendidikan Islam tidak bisa digantikan oleh mesin atau robotic, karena pendidikan bukan hanya transfer knowledge, namun juga attitude dan skill. Terjadinya degradasi akhlak dan moral hanya bisa dicegah dan diperbaiki melalui pendidikan. Di era millennial peran pendidikan Islam dalam upaya mencegah dan memperbaiki moral dan akhlak peserta didik sangat besar sebagai benteng dalam mempertahankan pengaruh dari hal-hal negative. Selanjutnya Sikap adaptif pendidik terhadap perkembangan ilmu pengetahuan dan teknologi merupakan keharusan, pendidik dituntut untuk terus belajar terhadap penguasaan teknologi baru yang dapat menunjang peningkatan mutu pendidikan. Dengan melakukan berbagai inovasi dalam dunia pendidikan tanpa harus menghilangkan nilai-niai Islam diharapkan mampu menyeimbangkan dan menyelaraskan sesuai kemajuan IPTEK. 


\section{DAFTAR PUSTAKA}

Annur, Cindi Mutia, dan Sorta Tobing. 2019. "Survei APJII: Penetrasi Pengguna Internet di Indonesia."

https://databoks.katadata.co.id/datapublish/2018/02/20/berapajumlah-pengguna-internet-di-indonesia (Oktober 14, 2019).

Arifin. 2009a. Ilmu Pendidikan Islam Tinjauan Teoritis dan Praktis berdasarkan Pendekatan Interdispliner. Jakarta: PT Bumi Aksara.

Arifin, Muzayyin. 2009b. Filsafat Pendidikan Islam. Jakarta: PT Bumi Aksara.

As'ad, Aliy. 2007. Terjemah Ta'limul Muta'allim. Kudus: Menara Kudus.

Marlina Widiyanti. 2019. "Trend Sistem Layanan Pendidikan di Perguruan Tinggi dalam Masyarakat Disruptif." Dalam UIN Raden Fatah Palembang.

Matranews. 2019. “Generasi Alpha, Apa Itu?” Konvergensi Majalah MATRA. https://matranews.id/generasi-alpha-apa-itu/ (Oktober 13, 2019).

Mubarak, Zaki. 2018. Pendidikan di Era Revolusi Industri 4.0 dan Problematika Pendidikan Tinggi. Yogyakarta: Ganding Pustaka.

Nata, Abuddin. 2018. "Pendidikan Islam Di Era Milineal." Conciencia 18(1): 10-28.

PCNU. 2017. "BETAPA PENTINGNYA GURU." PCNU Tulungagung. $\quad$ http://www.pcnutulungagung.or.id/betapapentingnya-guru/ (Oktober 14, 2019).

Prayitno. 2009. Dasar Teori dan Praksis Pendidikan. Jakarta: PT Grasindo. 
Putra, Yanuar Surya. 2016. "Teori Perbedaan Generasi." : 12.

Rahmawati, Fitri. 2018. "Kecenderungan Pergeseran Pendidikan Agama Islam Di Indonesia Pada Era Disrupsi." TADRIS: Jurnal Pendidikan Islam 13(2): 244-57.

Ramayulis. 2008. Ilmu Pendidikan Islam. Jakarta: Kalam Mulia.

Schwab, Klaus. 2019. Revolusi Industri Keempat. Jakarta: PT Gramedia Pustaka Utama.

Setyowati, Desi, dan Aria Pingit. 2018. "Pengguna Internet Indonesia Paling Suka Chatting dan Media Sosial - Katadata News." https://katadata.co.id/berita/2018/02/19/pengguna-internetindonesia-paling-suka-chatting-dan-media-sosial (Oktober 14, 2019).

Suharto, Toto. 2011. Filsafat Pendidikan Islam. Yogyakarta: Ar-Ruz Media.

Sukmadinata, Nana Syaodih. 2016. Pengembangan Kurikulum Teori dan Praktik. Bandung: PT. Remaja Rosdakarya.

Tafsir, Ahmad. 2006. Filsafat Pendidikan Islam. Bandung: Remaja Rosdakarya.

Umar, Bukhari. 2010. Ilmu Pendidikan Islam. Jakarta: AMZAH.

UU No. 20 Tahun. 2003. Undang-Undang Nomor 20 Tahun 2003 tentang Sistem Pendidikan Nasional. 